\title{
Pharmacological evaluation of a novel enhydrazone ester (CEE-1) as a dual inhibitor of the release of pro-inflammatory cytokines and prostanoids from human monocytes
}

\author{
Charles I. Ezeamuzie ${ }^{1 *}$, Hanan Zamil ${ }^{1}$, Hawraa Al-Baghli ${ }^{1}$, Ivan O. Edafiogho ${ }^{2}$ \\ ${ }^{1}$ Department of Pharmacology \& Toxicology, Faculty of Medicine, Kuwait University, Kuwait City, Kuwait \\ ${ }^{2}$ Department of Pharmaceutical Sciences, School of Pharmacy, University of Saint Joseph, Hartford, USA \\ Email: "ezeamuzie@,hsc.edu.kw
}

Received 8 June 2013; revised 8 July 2013; accepted 23 July 2013

Copyright (C) 2013 Charles I. Ezeamuzie et al. This is an open access article distributed under the Creative Commons Attribution License, which permits unrestricted use, distribution, and reproduction in any medium, provided the original work is properly cited.

\begin{abstract}
CEE-1 (ethyl 4-phenylhydrazinocyclohex-3-en-2-oxo6-phenyl-1-oate) - a novel enhydrazone ester, was tested in vitro for anti-inflammatory activity against the release of pro-inflammatory cytokine and prostanoid from lipopolysaccharide-activated human monocytes or human monocytic cell line (U937). The effects were compared with those of standard anti-inflammatory drugs dexamethasone and indomethacin. CEE-1 potently and strongly inhibited the release of both tumor necrosis factor-alpha (TNF- $\alpha$ ) and prostaglandin $\mathrm{E}_{2}\left(\mathrm{PGE}_{2}\right)$. The concentrations producing $50 \%$ inhibition (IC I0 values) were $2.0 \mu \mathrm{M}$ and $2.4 \mu \mathrm{M}$ for TNF$\alpha$ and $\mathrm{PGE}_{2}$, respectively. At $30 \mu \mathrm{M}$, the drug achieved almost complete inhibition of both mediators. Dexamethasone had similar effects but indomethacin inhibited only the $\mathrm{PGE}_{2}$ release, and although CEE-1 was less potent than these two drugs, it had comparable efficacy. The compound appeared to act, at least, in part by inhibiting the up-regulation of the mRNA for TNF- $\alpha$ as well as that of the prostanoid-synthetic enzyme, cyclo-oxygenase-2 (COX-2). However, like dexamethasone, but unlike indomethacin, CEE-1 did not affect COX-2 enzyme function. Thus, the profile of activity of CEE-1 is similar to that of steroids rather than the non-steroidal anti-inflammatory drugs. Structure-activity study showed that the presence of a simple aromatic ring attached via an NH-NH group was critical for activity. At the concentrations that completely inhibited mediator release, the compound displayed no significant in vitro toxicity on the cells. These results show that CEE-1 is a dual inhibitor of
\end{abstract}

"Corresponding author. the release of cytokines and prostanoids, and therefore could be a potential alternative to steroids in the treatment of inflammatory diseases.

Keywords: Enhydrazone Ester; Prostaglandin $\mathrm{E}_{2}$; Monocyte; Anti-Inflammatory; Tumor Necrosis Factor-Alpha; Cytokines

\section{INTRODUCTION}

Inflammation is the major cause or component of a wide range of chronic diseases such as rheumatoid arthritis, asthma, atopic dermatitis and inflammatory bowel disease [1-4]. Activated monocytes and macrophages contribute to inflammation by releasing a large number of proinflammatory mediators including cytokines such as TNF- $\alpha$, IL- $1 \beta$ and IL-6; eicosanoids such as leukotrienes and prostanoids; reactive oxygen species and lysosomal enzymes [5-8]. The mediators, in concert, orchestrate the inflammatory reactions that constitute the pathophysiology of the diseases. As a result, drugs that inhibit the synthesis and release of cytokines (such as steroids) or block the action of cytokines such as the disease modifying anti-rheumatic drugs (DMARDs), as well as inhibitors of prostanoid synthesis such as the non-steroidal anti-inflammatory drugs (NSAIDs), constitute the bulk of the therapeutic agents available for the management of chronic inflammatory diseases [9-11]. While very effective in inhibiting the synthesis of prostanoids, NSAIDs generally have little or no effect on the synthesis and release of pro-inflammatory cytokines. On the other hand, DMARDs, which comprise many structurally unrelated drugs, have widely differing mechanisms of anti-inflammatory action, but they generally have little or no effect 
on prostanoid synthesis [12]. The steroids are among the few anti-inflammatory drugs that are capable of inhibiting the generation of both cytokines and prostanoids, hence they are the most effective anti-inflammatory drugs available. They do this by preventing the transcription of the mRNA for the cytokines and the prostanoid synthetic enzyme - the cyclo-oxygenase (COX) enzyme $[13,14]$. However, the use of steroids is often associated with many adverse effects that tend to limit their clinical utility in long term therapy of chronic inflammatory diseases [15]. Thus, the need for new anti-inflammatory drugs that are capable of blocking the release of both cytokines and prostanoids has continued to be a research priority.

Enhydrazones are compounds which have in their structure a hydrazino (NH-NH) moiety that is joined to a keto group through a carbon-carbon double bond. The novel compound CEE-1 (ethyl 4-phenylhydrazinocyclohex-3-en-2-oxo-6-phenyl-1-oate) is a member of the series of enhydrazone esters recently synthesized by our group [16]. It can also be regarded as an isosteric analogue of benzyl enaminones. Although not much is known about the biological activities of enhydrazones, the enaminones to which they are related have been shown to possess a number of pharmacological activities including anti-convulsant [17,18], antitussive and immunosuppressive activities [19,20]. Following prior observations, that some enhydrazone esters may have significant anti-inflammatory activity, the current study was undertaken to investigate the anti-inflammatory activity of the lead compound CEE-1 with respect to its ability to inhibit the release of both cytokines and prostanoids in activated human primary monocytes and monocytic cell line (U937) in vitro.

\section{MATERIALS AND METHODS}

\subsection{Isolation and Culture of Human Monocytes}

Fresh heparinized blood samples were obtained from the Kuwait Central Blood Bank, after donor informed consent, and under a protocol approved by the Institutional Ethics Committee. Mononuclear cells were isolated by the ficoll gradient centrifugation method. Subsequently, highly purified monocytes ( $>98 \%$ purity), were isolated immunomagnetically using the Monocyte Negative Isolation kit (Invitrogen, Carlsbad, CA, USA), as previously described [21]. The viability (by trypan blue exclusion method) was $>97 \%$. Monocytes were washed twice and cultured in 96-well plate at a concentration of $5 \times$ $10^{5}$ cells $/ \mathrm{ml}$ in endotoxin-free complete culture medium (RPMI-1640 medium supplemented with $100 \mathrm{U} / \mathrm{ml}$ penicillin, $100 \mu \mathrm{g} / \mathrm{ml}$ streptomycin and $10 \%$ heat-inactivated fetal calf serum). The cells were then pre-incubated with the compounds (CEE-1, its analogues, standard anti-in- flammatory drugs or their solvents) for $30 \mathrm{~min}$ before being stimulated with $0.3 \mu \mathrm{g} / \mathrm{ml}$ LPS. All compounds were tested at concentrations ranging from $0.01 \mu \mathrm{M}$ to $30 \mu \mathrm{M}$. After $24 \mathrm{~h}$ of culture in a humidified incubator at $37^{\circ} \mathrm{C}$ and $5 \% \mathrm{CO}_{2}$, the supernatants were recovered by centrifugation and stored at $-40^{\circ} \mathrm{C}$ pending determination of the mediator contents.

In some experiments, human monocytic cell line (U937) was used. The cell line has the ability to release many inflammatory mediators including TNF- $\alpha$ and $\mathrm{PGE}_{2}$ following activation with a combination of 0.3 $\mu \mathrm{g} / \mathrm{ml}$ LPS and $50 \mathrm{nM}$ phorbol myristate acetate (PMA). The cells were cultured in complete culture medium (as above) and used undifferentiated between 5 - 10 passages.

In experiments to study the toxicity of the active compounds, cells were pre-treated with CEE- 1 for $24 \mathrm{~h}$. At the end of the culture, cells were gently scrapped and centrifuged for $5 \mathrm{~min}$ at $4^{\circ} \mathrm{C}$. The pellet was re-suspended and the viability determined as described above.

\subsection{Assay of Cytokines and Prostanoids}

The levels of the cytokines (TNF- $\alpha$, IL-1 $\beta$ and IL-6) and prostanoids $\left(\mathrm{PGE}_{2}\right.$ and $\left.\mathrm{TXB}_{2}\right)$ in the culture supernatants were determined using their respective commercially available ELISA kits obtained from R\&D systems (Minneapolis, MN, USA).

\subsection{Determination of mRNA Expression by Quantitative Real-Time Polymerase Chain Reaction (qRT-PCR)}

The expression of mRNA for TNF- $\alpha$ was studied on human blood monocytes. Purified cells were re-suspended and adjusted to a concentration of $10^{6}$ viable cells $/ \mathrm{ml}$, and $1.8 \mathrm{ml}$ aliquots added to each well of a 6 -well plate. They were then incubated for $1 \mathrm{~h}$ to adhere to the plate, pre-treated with vehicle or various concentrations of CEE-1 or standard anti-inflammatory drug dexamethasone for $30 \mathrm{~min}$ before being stimulated with LPS (1 $\mu \mathrm{g} / \mathrm{ml}$ ). After $2 \mathrm{~h}$ of culture (a time previously determined as optimal for mRNA expression), the cells were washed twice and then subjected to RNA extraction. For the determination of the expression of mRNA for COX-1 and COX-2, the human monocytic cells (U937) were used. The experimental procedure used was similar to the above except that the cells were stimulated with a combination of LPS $(0.3 \mu \mathrm{g} / \mathrm{ml})$ and PMA $(50 \mathrm{nM})$ and then cultured for $6 \mathrm{~h}$ (previously determined to be optimal for this cell line).

In both cases, total RNA extraction was performed using the Nucleospin ${ }^{\circledR}$ RNAII Total RNA Isolation kit (Machery-Nagel, Duren, Germany) and following manufacturer's instructions. The concentrations of the RNA in 
the samples were measured using a nano-spectrophotometer. Reverse transcription was carried out in a total volume of $20 \mu \mathrm{l}$ using the high-capacity cDNA reverse transcription kit (Applied Biosystems, Foster City, CA, USA) according to manufacturer's instructions. The qRT-PCR reaction was carried out using a TaqMan $^{\circledR}$ Gene Expression Assay GEX kit on the Applied Biosystems 7500 Fast Real-Time PCR System (Applied Biosystems). The Applied Biosystems assay ID numbers were [Hs00174128-m1 for TNF- $\alpha$, Hs00377726-m1 for COX1 and Hs00153133-m1 for COX-2. A B-actin TaqMan ${ }^{\circledR}$ control reagent kit (part \# 401846) was used as control.

The relative quantitation of the products was expressed as folds of the target over endogenous control.

\subsection{Determination of COX-2 Protein Expression by Western Blotting}

Aliqouts of U937 monocytes $\left(2 \times 10^{6}\right.$ cells $)$ were added to each well of a 24-well plate and pre-incubated with CEE-1 $(30 \mu \mathrm{M})$, indomethacin $(1 \mu \mathrm{M})$ or vehicle (as control) for $30 \mathrm{~min}$ before being stimulated with a combination of LPS $(0.3 \mu \mathrm{g} / \mathrm{ml})$ and PMA $(50 \mathrm{nM})$. After 24 $\mathrm{h}$ culture, the cells were washed and the pellet lysed with $150 \mu \mathrm{l}$ of RIPA lysis buffer (1X) per sample. Following thorough mixing, the lysates were placed on ice for 40 $\min$ before being centrifuged for $5 \mathrm{~min}$ at $10,000 \mathrm{~g}$. The supernatants were collected and the protein contents determined by the Bradford protein assay method.

For the Western blotting experiments, an aliquot of 12 $\mu \mathrm{g}$ protein from each sample in $6 \mathrm{x}$ loading buffer was boiled for $5 \mathrm{~min}$ at $100^{\circ} \mathrm{C}$ and electrophoresed in a $10 \%$ acrylamide gel containing 10\% SDS (SDS-PAGE). Proteins were subsequently transferred to a polyvinyl difluoride (PVDF) membrane, washed and blocked with $15 \mathrm{ml}$ blocking reagent ( $15 \mathrm{ml}$ TBS Blotto $\mathrm{A}+15 \mu \mathrm{l}$ Tween 20) for $1 \mathrm{~h}$ at room temperature. Thereafter, the membrane was incubated with primary antibodies against COX-2 (mouse monoclonal IgG anti-human COX-2, diluted 1:500) overnight at $4^{\circ} \mathrm{C}$. The membrane was then washed 3 times for 5 min each, followed by incubation with secondary antibody (HRP-labeled goat anti-mouse $\mathrm{IgG}$, diluted 1:2000) for $1 \mathrm{~h}$ at room temperature. After three further washings, the bound antibody was detected using the luminol reagent solution and exposed on X-ray film. The same blotting procedure was used for the $B$-actin after striping of the membrane.

\subsection{Determination of the Effect of CEE-1 on COX Enzyme Function}

Cyclo-oxygenase-2 enzyme function was assessed as $\mathrm{PGE}_{2}$ production occurring within 4 min of the addition of exogenous arachidonic acid (AA) in U937 monocytes that have been pre-activated for $24 \mathrm{~h}$ with a combination of LPS and PMA, to up-regulate COX-2 protein (as mentioned above). Pre-activated cells were washed twice and then incubated with various concentrations of CEE-1, indomethacin $(1 \mu \mathrm{M})$, aspirin $(250 \mu \mathrm{M})$, dexamethasone $(0.3 \mu \mathrm{M})$ or solvent for $30 \mathrm{~min}$ before the addition of AA $(5 \mu \mathrm{M})$. After $4 \mathrm{~min}$, the reaction was rapidly terminated by placing the plate on ice for $1 \mathrm{~min}$ and centrifuging at $450 \mathrm{~g}$ at $4^{\circ} \mathrm{C}$ for $3 \mathrm{~min}$. Finally, supernatants were collected and stored at $-80^{\circ} \mathrm{C}$ pending $\mathrm{PGE}_{2}$ assay.

\subsection{Determination of the Effect of CEE-1 on Cell Viability}

The effect of CEE-1 on cell viability was determined in primary human monocytes by measuring the induction of apoptosis using the annexin $\mathrm{V}$ binding/flow cytometry method. Monocytes were cultured at a concentration of 5 $\times 10^{5}$ cells $/ \mathrm{ml}$ in 48 -well plate (in duplicate) in the presence of CEE-1 $(3,10$ and $30 \mu \mathrm{M})$ or vehicle for $24 \mathrm{~h}$. After culture, cells were centrifuged at $450 \mathrm{~g}$ for $5 \mathrm{~min}$ $4^{\circ} \mathrm{C}$ and the supernatant removed. After one wash in PBS, adherent cells were recovered by treatment with $1 \mathrm{mM}$ EDTA solution in PBS for $3 \mathrm{~min}$ at room temperature. The cells were then washed again and incubated for 15 min with a mixture of FITC-labeled monoclonal antiannexin $\mathrm{V}$ antibody and the vital dye 7-amino-actinomycin D (7-AAD). Total apoptotic cells (annexin-positive/7-AAD-negative and annexin-positive/7-AAD-positive, representing early apoptosis and late apoptosis/ necrosis, respectively), were then determined by flow cytometry using Cytomics FC500, flow cytometer (Beckman-Coulter, Brea, CA, USA).

\subsection{Materials}

The compound CEE-1 and its analogues CEE-2, BRG-14 and EMP-12 were synthesized as previously described $[16,18]$. The compounds were prepared fresh each time; first dissolved in dimethyl sulphoxide (DMSO) and subsequently diluted down in culture medium. The highest final solvent concentration in the wells did not exceed $0.05 \%$ - a concentration that had no significant effect on macrophage/monocyte responses.

The following drugs and reagents were obtained from Sigma-Aldrich (St. Louis, MO, USA): dexamethasone, indomethacin, DMSO, fetal calf serum, heparin, PMA, L-glutamine, LPS, aspirin, penicillin/streptomycin solution, RPMI 1640 medium, beta-mercaptoethanol, bisacrylamide N,N'-methylene-bis-acryl-amide, sodium dodecyl sulfate (SDS), bromophenol blue and tris-base. The U937 cell line was purchased from American Tissue Collection Center (Manassas, VA, USA). Minitrans blot filter paper, immuno-blot ${ }^{\circledR}$ PVDF membrane for protein blotting $(0.2 \mu \mathrm{M})$ and protein assay reagents were all obtained from Bio-Rad Systems, (Herculus CA, USA). 
The ELISA kits for TNF- $\alpha$, IL- $1 \beta$, IL-6, $\mathrm{PGE}_{2}$ and $\mathrm{TXB}_{2}$ were all purchased from R\&D Systems (Minneapolis MN, USA). Nucleospin RNA II kit was purchased from Macherey-Nagel (Duren, Germany), whereas high-capacity cDNA reverse Transcription Kit, TaqMan ${ }^{\circledR}$ Gene Expression Master Mix, TaqMan ${ }^{\circledR}$ Gene Expression Assay GEX kit and control reagents were purchased from Applied Biosystems (Foster City, CA, USA). Mouse monoclonal IgG anti-human COX-1 or COX-2 or $\beta$-actin antibodies, as well as the HRP-labeled goat antimouse IgG were all obtained from Santa Cruz Biotechnology (Santa Cruz, CA, USA). Annexin V-FITC/7AAD kit (containing mouse anti-human annexin $\mathrm{V}$ antibody and the vital dye 7-AAD) as well as the antibody isotype control (mouse IgG1-FITC) were obtained from Beckman-Coulter, Brea, CA, USA.

\subsection{Statistics}

Data were analyzed using GraphPad Prism software (GraphPad Software, San Diego, CA, USA). All results were expressed as the mean $\pm \mathrm{SEM}$. The $\mathrm{IC}_{50}$ values were calculated from the concentration-response curves by non-linear regression analysis. Differences between mean values were evaluated for statistical significance using one-way ANOVA, followed by Bonferroni's posthoc test or one-sample t-test as appropriate. Differences were considered significant when $\mathrm{p} \leq 0.05$.

\section{RESULT}

\subsection{Effect of CEE-1 on the Release of TNF-a and Other Cytokines from Activated Monocytes}

As shown in Figure 1(a), pre-treatment of human blood monocytes with CEE-1 for $30 \mathrm{~min}$ before stimulation with LPS resulted in a strong and concentration-dependent inhibition of the release of TNF- $\alpha$. The concentration causing $50 \%$ inhibition of release $\left(\mathrm{IC}_{50}\right.$ value) was $2.0 \pm 0.4 \mu \mathrm{M}$, and at $30 \mu \mathrm{M}$ almost complete inhibition was achieved. A comparison with two standard anti-inflammatory drugs - dexamethasone (a steroid) and indomethacin (a non-steroidal anti-inflammatory drug), showed that CEE-1 was about 45 times less potent than dexamethasone $\left(\mathrm{IC}_{50}\right.$ value $\approx 45 \mathrm{nM}$ ), but the efficacy (maximal effect) of both drugs were comparable $(95 \%$ $100 \%$ inhibition). As expected, indomethacin had no inhibitory effect at all concentrations tested. Similar effects were seen when the drugs were tested on human monocytic cell line (U937) following stimulation with a combination of LPS and PMA (Figure 1(b)). The $\mathrm{IC}_{50}$ values were $\approx 4.4 \mu \mathrm{M}$ and $87.5 \mathrm{nM}$ for CEE-1 and dexamethasone, respectively.
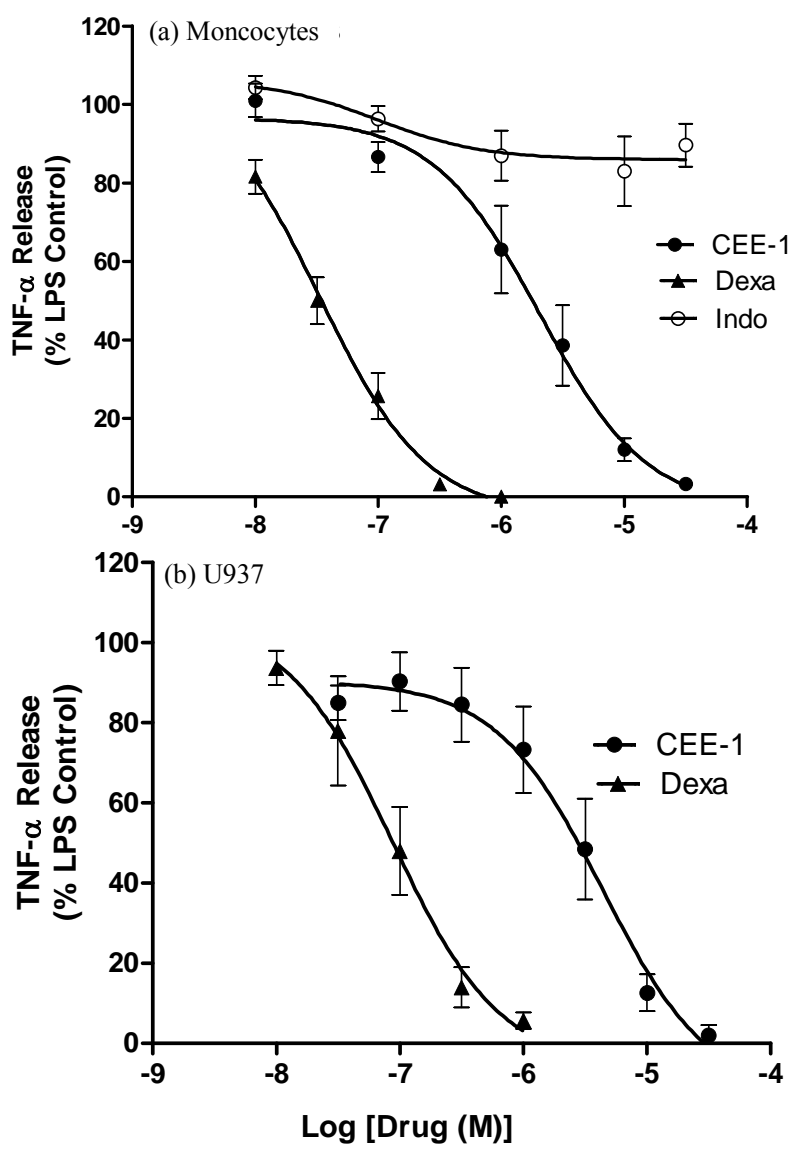

Figure 1. Concentration-dependent effect of CEE-1 on the release of TNF- $\alpha$ from human blood monocytes stimulated with $0.3 \mu \mathrm{g} / \mathrm{ml}$ LPS (a), or from undifferentiated human monocytic cell line (U937) stimulated with a combination of LPS (0.3 $\mu \mathrm{g} / \mathrm{ml})$ and PMA (50 $\mathrm{nM})(\mathrm{b})$. In both cases, the compound was compared with the steroid dexamethasone (dexa) or the NSAID indomethacin (indo). Cells were pre-treated with the drugs or vehicle for $30 \mathrm{~min}$ before stimulation and culture for $24 \mathrm{~h}$. Net un-inhibited releases were in the range $875-3120 \mathrm{pg} / 10^{6}$ cells for human monocytes and $1452-2274 \mathrm{pg} / 10^{6}$ cells for U937 cells. Data are presented as mean $\pm \mathrm{SEM}$ of $\mathrm{N}=5$ - 9 .

Apart from TNF- $\alpha$, CEE-1 also inhibited the release of other pro-inflammatory cytokines. As shown in Figure 2, it significantly inhibited, in a concentration-dependent manner, the release of IL- $1 \beta$ and IL- 6 . The drug was at least 10 times more potent in inhibiting the production of IL-1 $\beta$ than IL-6 ( $\mathrm{IC}_{50}$ values of $0.25 \mu \mathrm{M}$ and $3.0 \mu \mathrm{M}$, respectively).

In order to determine the structural requirement for activity, we synthesized and tested 3 analogues of CEE-1 (CEE-2, EMP-12 and BRG-14) that incorporated different modifications on the enhydrazone pharmacophore. CEE-2 is structurally very close to CEE-1 except that the ethyl-group attached to the carboxyl moiety was replaced with a methyl-group. EMP-12 is a 2,4-dinitro-substituted CEE-1, while BRG-14 is an analogue of CEE-1 that lacks the hydrazino (NH-NH) moiety. As shown in Fi- 


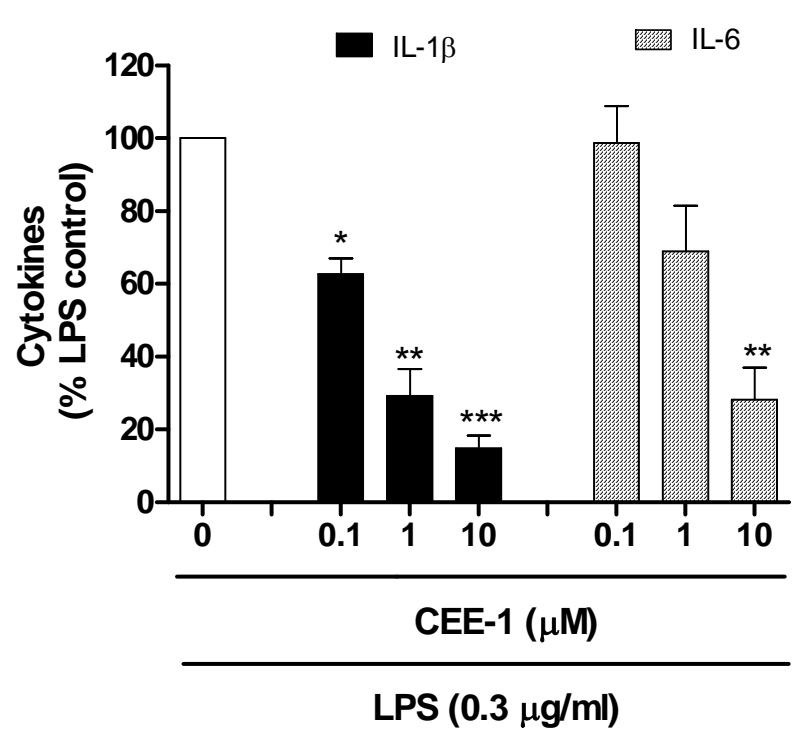

Figure 2. Concentration-dependent effect of CEE-1 on the release of other cytokines (IL-1 $\beta$ and IL-6) from human blood monocytes stimulated with $0.3 \mu \mathrm{g} / \mathrm{ml}$ LPS. Cells were pre-treated with the drugs or vehicle for $30 \mathrm{~min}$ before stimulation and culture for $24 \mathrm{~h}$. Net un-inhibited releases were in the range $185-588 \mathrm{pg} / 10^{6}$ cells for IL- $1 \beta$ and $4300-11,100 \mathrm{pg} / 10^{6}$ cells for IL-6. Data are presented as mean \pm SEM of $\mathrm{N}=4-5$. ${ }^{*} \mathrm{p}<$ $0.05 ;{ }^{* * *} \mathrm{p}<0.01 ;{ }^{* * *} \mathrm{p}<0.001$.

gure 3, CEE-2 had almost identical activity with the parent compound (CEE-1) in inhibiting TNF- $\alpha$ release from activated human monocytes $\left(\mathrm{IC}_{50} \approx 3.2 \mu \mathrm{M}\right)$. In contrast, EMP-12 and BRG-14 had very weak or no antiinflammatory activity, thus indicating that the presence of the hydrazino functional group as well as an unsubstituted aromatic ring linked to this hydrazino group were critical requirements for anti-inflammatory activity.

\subsection{Effect of CEE-1 on the Release of Prostanoids from Monocytes}

To study the effect of CEE-1 on the release of prostanoids from monocytes, undifferentiated U937 cells were used. As shown in Figure 4, treatment of the cells with the drug for $30 \mathrm{~min}$ prior to stimulation with a combination of LPS $(0.3 \mu \mathrm{g} / \mathrm{ml})$ and PMA $(50 \mathrm{nM})$ resulted in a pronounced concentration-dependent inhibition of $\mathrm{PGE}_{2}$ production. The $\mathrm{IC}_{50}$ value was $2.4 \pm 0.6 \mu \mathrm{M}$, and at 30 $\mu \mathrm{M}$, the inhibition of was almost complete (95\%). Similarly, both dexamethasone and indomethacin also produced strong inhibitory effects, with $\mathrm{IC}_{50}$ values of 75 $\mathrm{nM}$ and $32 \mathrm{nM}$, respectively. Thus, even though CEE-1 was about 30 and 76 times less potent than dexamethasone and indomethacin, respectively, it has a comparable efficacy (maximal effect) of almost 100\% inhibition. Similar results were obtained with the release of $\mathrm{TXB}_{2}(\mathrm{a}$ stable surrogate of $\mathrm{TXA}_{2}$ ) (data not shown).

\subsection{Effect of CEE-1 on mRNA Expression}

In order to determine the mechanism by which CEE-1 inhibited the production of TNF- $\alpha$ and prostanoids, the effect of the drug on the expression of mRNA for both TNF- $\alpha$ and COX were studied by the qRT-PCR method. As shown in Figure 5(a), pre-treatment of human blood monocytes with CEE-1 for $30 \mathrm{~min}$ before stimulation with LPS $(1 \mu \mathrm{g} / \mathrm{ml})$ produced a concentration-dependent inhibition of the up-regulation of mRNA for TNF- $\alpha$. However, only at the higher concentration of $30 \mu \mathrm{M}$ did the inhibition $(56.8 \pm 6.4 \%)$ reach statistical significance ( $\mathrm{p}<0.05)$. In comparison, dexamethasone $(0.3 \mu \mathrm{M})$ completely abolished the response. A similar effect was also seen in the inhibition of COX-2 mRNA up-regulation by CEE-1 in U937 cells stimulated with a combination of LPS $(0.3 \mu \mathrm{g} / \mathrm{ml})$ and PMA (50 nM), (Figure 5(b)). As would be expected, dexamethasone $(0.3 \mu \mathrm{M})$, but not indomethacin $(1 \mu \mathrm{M})$ was effective in inhibiting COX-2 mRNA up-regulation. Stimulation with the above protocol did not result in any significant up-regulation of COX-1 mRNA expression over the time frame of the experiments, neither did pre-treatment with CEE-1 or other drugs have any significant effect on the basal level.

\subsection{Effect of CEE-1 on the COX-2 Protein Expression and Function}

To determine if the effect on COX-2 mRNA expression was reflected in COX-2 protein expression, the Western blotting analysis was used to quantify COX-2 protein in whole cell lysates. As shown in Figure 6(a), activation of U937 cells with the combination of LPS and PMA, resulted in increased expression of the COX-2 protein after $24 \mathrm{~h}$ of culture. The increase was essentially prevented by prior treatment of the cells with CEE-1 (30 $\mu \mathrm{M})$, but not indomethacin $(1 \mu \mathrm{M})$.

To investigate whether CEE-1 also acted by inhibiting the function of the COX-2 enzyme, the effect of the drug on the conversion of exogenous $\mathrm{AA}$ into $\mathrm{PGE}_{2}$ in cells pre-activated for $24 \mathrm{~h}$ to up-regulate $\mathrm{COX}-2$ protein was investigated. As shown in Figure 6(b), the drug had no effect on $\mathrm{PGE}_{2}$ production at concentrations of $10 \mu \mathrm{M}$ and $30 \mu \mathrm{M}$. As expected, the two NSAIDs, indomethacin $(1 \mu \mathrm{M})$ and Aspirin $(250 \mu \mathrm{M})$, both produced significant inhibitory effects of $81 \%(\mathrm{p}<0.001)$ and $59 \%(\mathrm{p}<0.01)$, respectively, while the steroid dexamethasone $(0.3 \mu \mathrm{M})$ had no effect.

\subsection{Effect of CEE-1 on Viability of Monocytes}

To verify that the anti-inflammatory activity of CEE-1 was not due to toxicity to the cells, we analyzed the effect of the drug on apoptosis of human primary monocytes using the annexin $\mathrm{V}$ binding/flow cytometry method. As shown in Figure 7, culturing the cells with 


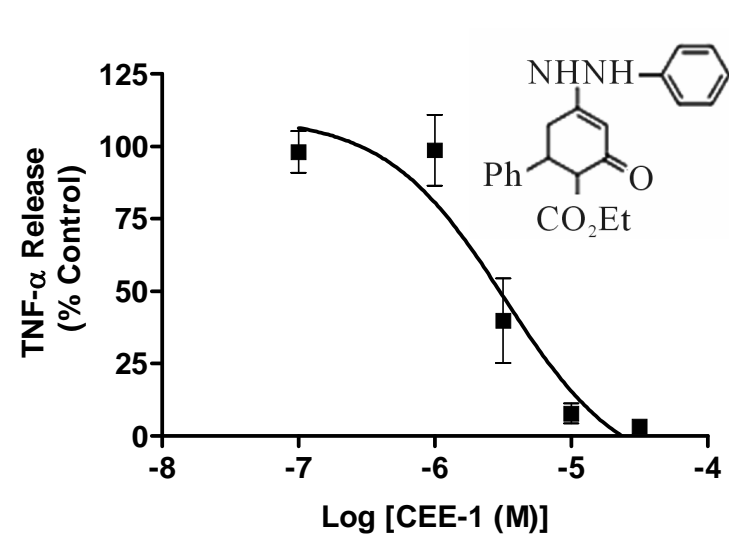

(a)

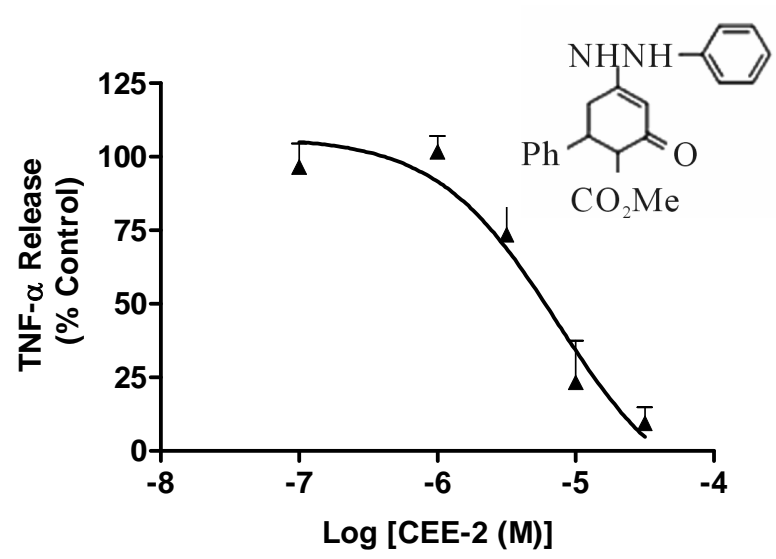

(b)

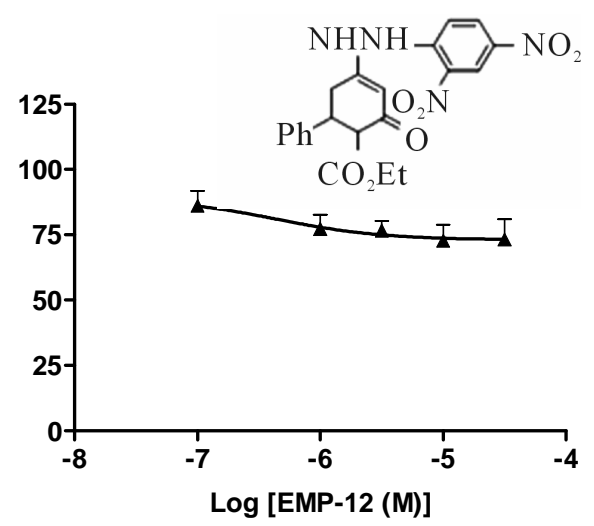

(c)

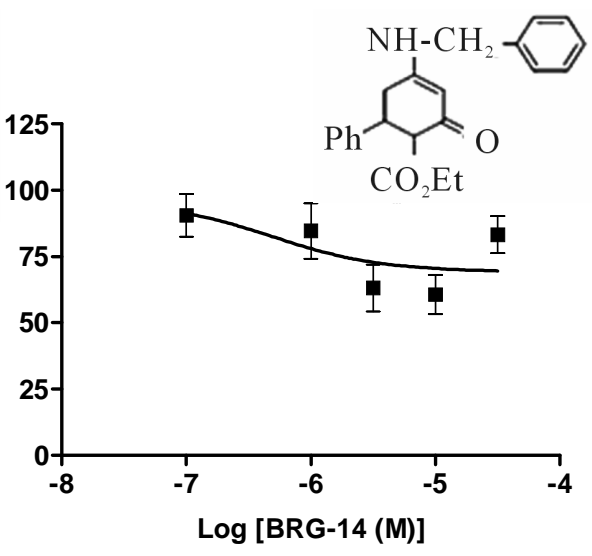

(d)

Figure 3. Structure-activity relationship illustrating the effect of structural modifications of CEE-1 on the inhibition of LPS-induced TNF- $\alpha$ release in human blood monocytes. The pronounced inhibitory effect of CEE-1 (a) was retained by the analogue CEE-2 in which the ethylcarboxy-group was replaced by a methylcarboxy-group (b) Dinitro-substitutions in the aromatic ring linked to the hydrazino (NH-NH) group, as in EMP-12, (c) and the absence of the hydrazino (NH-NH) group, as in BRG-14, (d) resulted in almost complete loss of activity. In all cases, cells were pre-treated with the compounds for $30 \mathrm{~min}$ before stimulation with LPS $(0.3 \mu \mathrm{g} / \mathrm{ml})$. Net un-inhibited releases were in the range $993-1806 \mathrm{pg} / 10^{6}$ cells. Data are presented as mean $\pm \mathrm{SEM}$ of $\mathrm{N}=4$.

CEE- 1 at the concentrations of 3,10 or $30 \mu \mathrm{M}$ for $24 \mathrm{~h}$ did not significantly increase total apoptosis (both early and late) when compared to vehicle-treated cells.

\section{DISCUSSION}

The treatment of chronic inflammatory diseases has been notoriously difficult, partly because of the multiple and often cross-talking, classes of mediators involved in their pathophysiology [22,23]. With the exception of the steroids, most available anti-inflammatory drugs are capable of affecting only a single mediator or class of mediators, with the result that efficacy is often low. On the other hand, the use of steroids for long term therapy is limited by adverse effects [15]. In this work, we have shown that the novel enhydrazone ester CEE-1 is a potential anti-inflammatory agent that inhibits the production of both prostanoids and cytokines from activated human blood monocytes and monocytic cell line (U-937). This dual action profile is similar to that of the steroids. Although CEE-1 was generally less potent than the standard anti-inflammatory drugs - dexamethasone and indomethacin, (representing the steroidal and the non-steroidal anti-inflammatory drugs, respectively), it had similar efficacy (maximal effect), producing nearly complete inhibition of the release of both cytokines and prostanoids at a reasonably low concentration range of $10-30$ $\mu \mathrm{M}$.

To the best of our knowledge, this is the first report describing a potentially useful anti-inflammatory effect for any enhydrazone ester, although certain enaminones which are structurally related to the enhydrazones (but lack the hydrazino group), have been shown to have a number of pharmacological activities including anti-convulsant, anti-tussive and immunosuppressive effects 


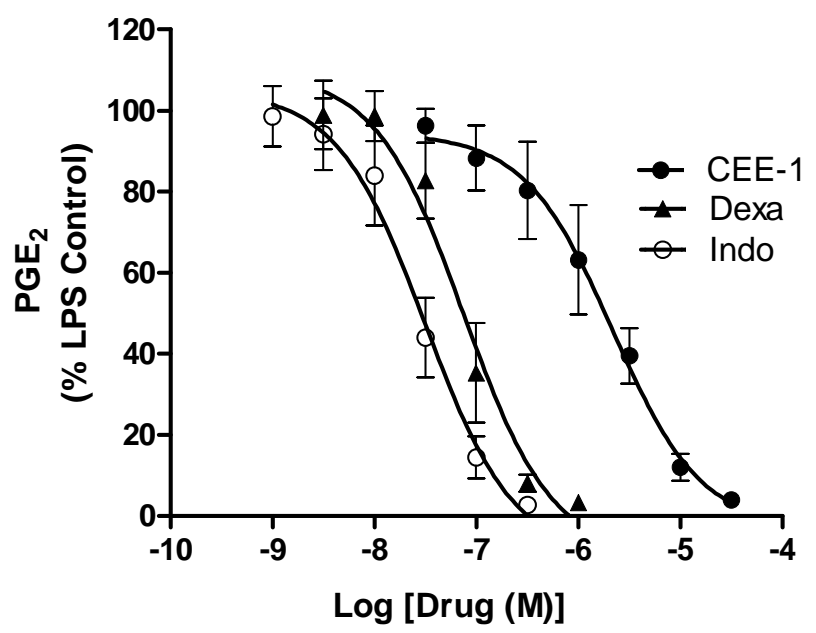

Figure 4. Concentration-dependent effect of CEE-1 on the release of the prostanoid $\mathrm{PGE}_{2}$ from undifferentiated human monocytic cell line (U937) stimulated with a combination of LPS $(0.3 \mu \mathrm{g} / \mathrm{ml})$ and PMA $(50 \mathrm{nM})$, in comparison with the steroid dexamethasone (dexa) and the NSAID indomethacin (indo). Cells were pre-treated with the drugs or vehicle for $30 \mathrm{~min}$ before stimulation and were thereafter cultured for $24 \mathrm{~h}$. Data are presented as mean \pm SEM of $\mathrm{N}=7-11$. The net amount of $\mathrm{PGE}_{2}$ produced by cells that were stimulated but vehicletreated was $722 \pm 56.4 \mathrm{pg} / 10^{6}$ cells.

\section{$[17,19,20]$.}

Structure-activity studies demonstrated that analogues of the compound that lacked the hydrazino group (as in compound BRG-14) or had a 2,4-dinitro substitution on the aromatic ring attached to this hydrazino group (as in compound EMP-12) had little or no anti-inflammatory activity. In contrast, the replacement of the carboxyethylgroup with a carboxymethyl-group, (as in compound CEE-2) led to no loss of activity. These observations show that the action of CEE-1 is specific and that the presence of the hydrazino functional group attached to a simple aromatic ring is a critical requirement for anti-inflammatory activity of enhydrazone esters.

Mechanistically, CEE-1 appears to inhibit the production of both cytokines and prostanoids by the same basic mechanism, which is the suppression of the up-regulation of the mRNA expression for the relevant cytokine $(\mathrm{TNF}-\alpha)$ or the prostanoid-synthetic enzyme-COX-2. The suppressive effect of CEE-1 on COX-2 mRNA expression was also clearly reflected in the decreased level of expression of the protein itself. A similar mechanism is utilized by the steroids [14]. Furthermore, like the steroids but unlike the NSAIDs, CEE-1 had no effect on COX enzyme function, since it failed to effect the AA-dependent generation of $\mathrm{PGE}_{2}$ in cells in which COX-2 had been previously induced. At the concentration at which the drug blocked COX-2 mRNA up-regulation, it did not affect basal level of COX-1 mRNA. This indicates that the compound is unlikely to be associated

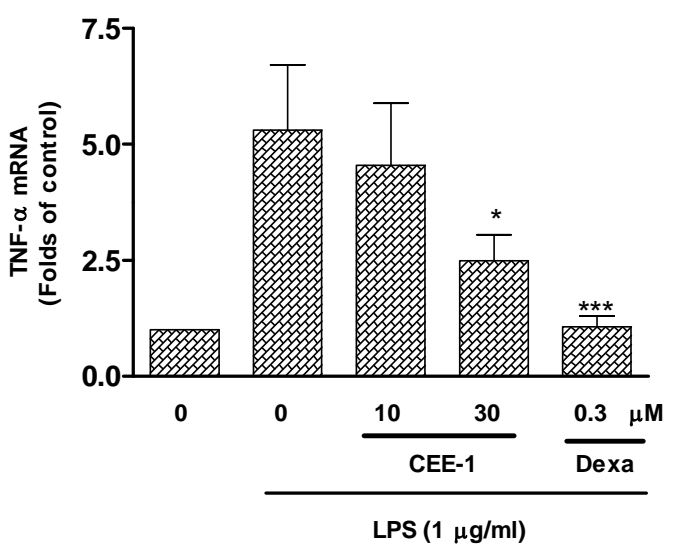

(a)

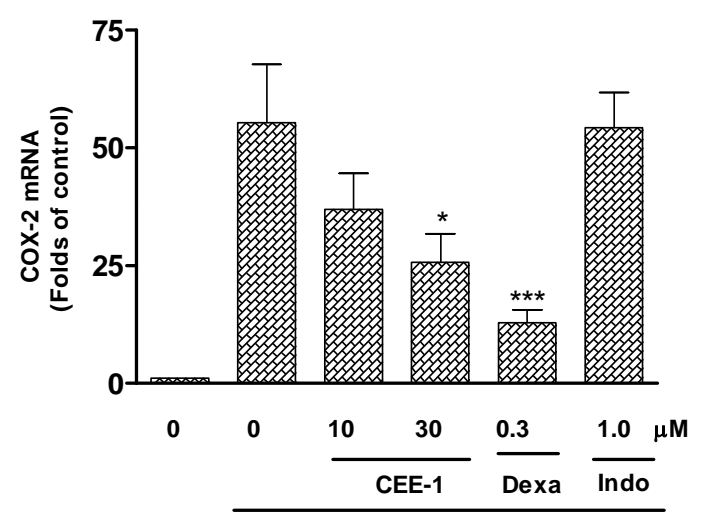

LPS $(0.3 \mu \mathrm{g} / \mathrm{ml})+$ PMA $(50 \mathrm{nM})$

(b)

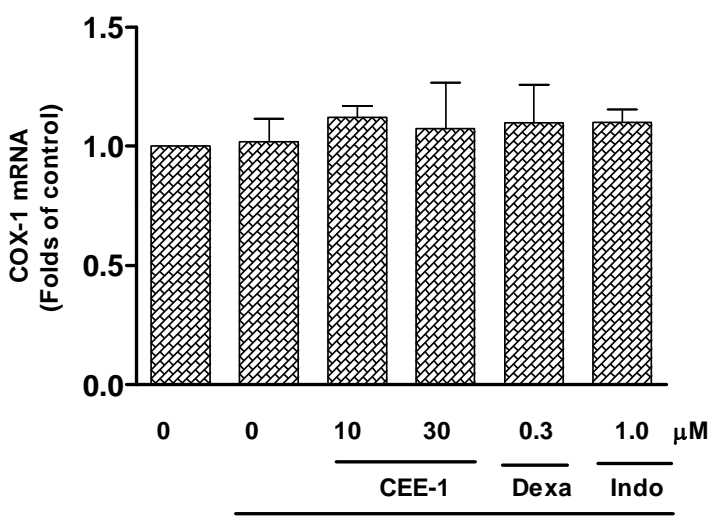

LPS $(0.3 \mu \mathrm{g} / \mathrm{ml})+$ PMA $(50 \mathrm{nM})$

(c)

Figure 5. Quantitative real-time PCR analysis of the effect of CEE-1 on the up-regulation of the mRNA for TNF- $\alpha$ in human blood monocytes stimulated with 1 $\mu \mathrm{g} / \mathrm{ml}$ LPS (a) or the mRNA for COX-2 (b) and COX1 (c) in U937 monocytes stimulated with a combination of LPS $(0.3 \mu \mathrm{g} / \mathrm{ml})$ and PMA $(50 \mathrm{nM})$. Cells were pre-treated with CEE-1, dexamethasone (dexa), indomethacin (indo) or vehicle for $30 \mathrm{~min}$ before stimulation. RNA extraction was carried out $2 \mathrm{~h}$ after stimulation for TNF- $\alpha$ and $6 \mathrm{~h}$ after stimulation for COX-1 and COX-2. Values are means \pm SEM of $N=5{ }^{*} \mathrm{p}<$ $0.05 ;{ }^{* * *} \mathrm{p}<0.001$. 


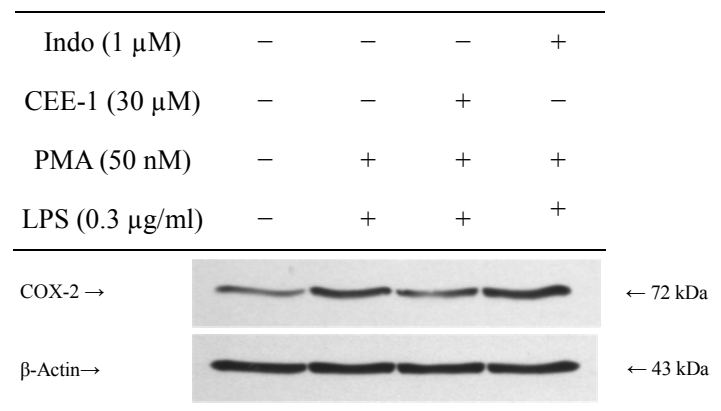

(a)

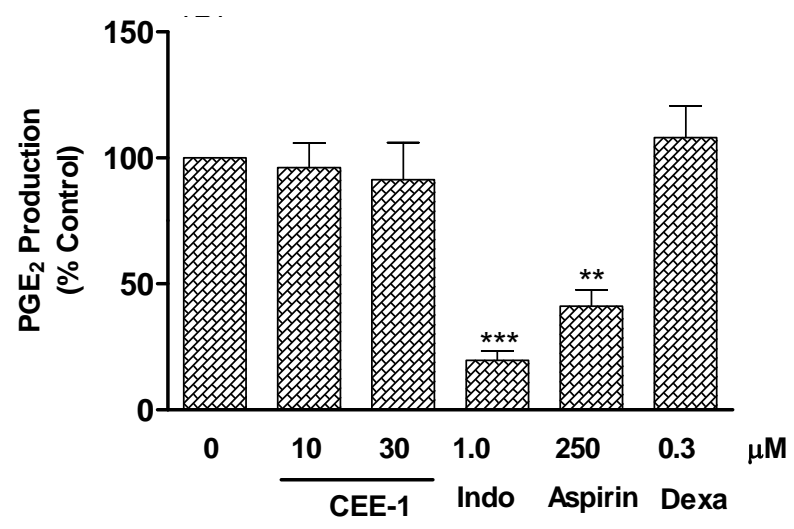

(b)

Figure 6. Effect of CEE-1 on COX-2 protein expression and function in U937 monocytes. (a) Western blot analysis of the effect of CEE-1 on the expression of COX-2 protein in cells stimulated with a combination of LPS $(0.3 \mu \mathrm{g} / \mathrm{ml})$ and PMA $(50 \mathrm{nM})$. Cells were pre-treated with CEE-1, indomethacin or vehicle for $30 \mathrm{~min}$ before stimulation. Cell lysates were prepared after $24 \mathrm{~h}$ of culture post-stimulation. Result is representative of two other independent experiments with similar results. (b) Analysis of the effect of CEE-1 on $\mathrm{PGE}_{2}$ generation from exogenously added arachidonic acid (AA) as a function of COX-2 enzyme activity. U937 monocytes were first stimulated as above for $24 \mathrm{~h}$ to up-regulate COX-2 enzyme. The preactivated cells were then washed and treated with CEE-1, vehicle or other drugs for $30 \mathrm{~min}$ before addition of AA $(5 \mu \mathrm{M})$. Four min later, the supernatants were recovered for determination of $\mathrm{PGE}_{2}$. The net un-inhibited $\mathrm{PGE}_{2}$ release from added AA was $1341 \pm 436 \mathrm{pg} / 10^{6}$ cells. Values are means $\pm \mathrm{SEM}$ of $\mathrm{N}$ $=5 .^{* *} \mathrm{p}<0.01 ;{ }^{* * *} \mathrm{p}<0.001$.

with adverse effects known to be related to COX-1 inhibition $[24,25]$. Thus, in terms of mechanism of action, CEE-1 appears to behave more like steroids than NSAIDs. Perhaps, a notable inconsistency in this regard is the fact that higher concentrations of CEE-1 were required for the inhibition of mRNA expressions (for both TNF- $\alpha$ and COX-2) than for the inhibition of the release of the mediators in culture. For example, at the concentration of $10 \mu \mathrm{M}$, the inhibitory effect of CEE-1 on the expression of mRNA for TNF- $\alpha$ and COX-2 enzyme did not reach statistical significance, whereas at the same concentration, the release of both TNF- $\alpha$ and $\mathrm{PGE}_{2}$ was more than $65 \%$ inhibited. Thus, the suppression of

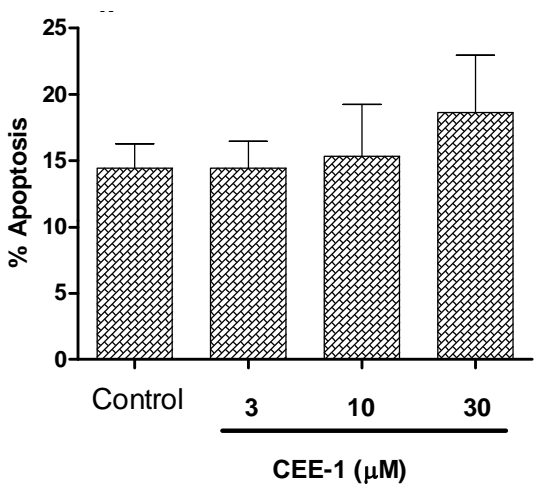

(a)

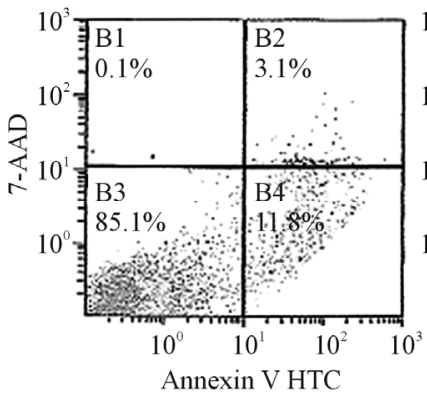

(b)

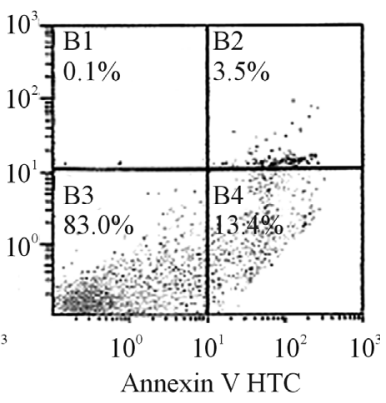

(c)

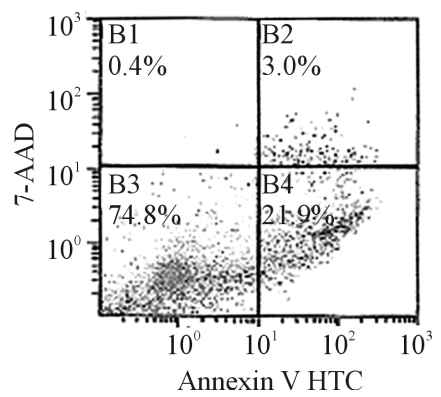

(d)

Figure 7. The effect of CEE-1 on apoptosis of human blood monocytes. Apoptosis was determined by the annexin $\mathrm{V}$ binding/7-AAD uptake analysis using the flow cytometry method. Cells were cultured with the drug $(3,10$ or $30 \mu \mathrm{M})$ or vehicle for $24 \mathrm{~h}$ before staining and analysis. Values represent total apoptotic cells (annexin-positive/7-AAD-negative and annexinpositive/7-AAD-positive, representing early apoptosis and late apoptosis/necrosis, respectively) and include both adherent and floating cells. A: Values are means $\pm \mathrm{SEM}$ of $\mathrm{N}=4$. $\mathrm{B}, \mathrm{C}$ and $D$ : Values are representative scatter plots for cells treated with vehicle, $10 \mu \mathrm{M}$ or $30 \mu \mathrm{M}$ CEE-1, respectively.

mRNA expression did not appear to fully account for the level of inhibition of the release of mediators seen. This may suggest that additional mechanism(s) were possibly involved. Post-transcriptional regulation of the transcribed mRNA and alteration in the rate of decay of such mRNA are some of the possible mechanisms of amplification of the overall outcome of gene transcription [26,27].

Furthermore, the activity of CEE-1 appeared not to be 
a result of direct toxicity to the cells since at the concentration at which the drug completely inhibited mediator production from human primary monocytes, it caused no significant induction of apoptosis or necrosis over a $24 \mathrm{~h}$ culture period. Although a small tendency towards early apoptosis was seen at $30 \mu \mathrm{M}$, this is unlikely to be important in the action of the drug since at $10 \mu \mathrm{M}$ concentration, at which the drug produced no observable increase in apoptosis, it inhibited mediator release by over $65 \%$.

Further studies are on-going to evaluate the in vivo anti-inflammatory effects and tolerability in suitable animal models.

In conclusion, we have provided evidence that the novel enhydrazone ester CEE-1 is an effective inhibitor of in vitro production of pro-inflammatory cytokines and prostanoids from activated human monocytes. This activity appeared to depend on the presence of the hydrazino (NH-NH) functional group linked to a simple aromatic ring. Its mechanism of action, at least in part, involves the inhibition of the transcription of the genes for TNF- $\alpha$ and the COX-2 enzymes, without affecting COX enzyme function. This profile of activity, which is similar to that of steroids, rather than NSAIDs, makes CEE-1 a potential alternative to steroids in the treatment of inflammatory diseases. Furthermore, enhydrazone esters may represent a novel group of compounds with potentially useful anti-inflammatory activity.

\section{ACKNOWLEDGEMENTS}

This work was supported by grant \# MR 03/09 from Research Administration, Kuwait University, Kuwait. We acknowledge the Research Core Facility of the HSC, Kuwait University, (Grant \# GM 01/01), for assistance with the use of flow cytometer. We are grateful to Ms Elizabeth Philip, Mr P. K. Shihab and Mr. T. K. Jacob for their excellent technical assistance.

\section{REFERENCES}

[1] Barnes, P.J. (2008) Immunology of asthma and chronic obstructive pulmonary disease. Nature Reviews Immunology, 8, 183-192. doi:10.1038/nri2254

[2] Cooles, F.A. and Isaacs, J.D. (2011) Pathophysiology of rheumatoid arthritis. Current Opinion in Rheumatology, 23, 233-240. doi:10.1097/BOR.0b013e32834518a3

[3] Homey, B., Steinhoff, M., Ruzicka, T. and Leung, D.Y. (2006) Cytokines and chemokines orchestrate atopic skin inflammation. Journal of Allergy and Clinical Immunology, 118, 178-189. doi:10.1016/j.jaci.2006.03.047

[4] Ohman, L. and Simren, M. (2010) Pathogenesis of IBS: role of inflammation, immunity and neuroimmune interactions. Nature Reviews Gastroenterology \& Hepatology, 7, 163-173. doi:10.1038/nrgastro.2010.4

[5] Fujiwara, N. and Kobayashi, K. (2005) Macrophages in inflammation. Current Drug Targets-Inflammation \& Allergy, 4, 281-286. doi:10.2174/1568010054022024

[6] Borish, L.C. and Steinke, J.W. (2003) Cytokines and chemokines. Journal of Allergy and Clinical Immunology, 111, S460-475. doi:10.1067/mai.2003.108

[7] Rahman, I. (2002) Oxidative stress and gene transcription in asthma and chronic obstructive pulmonary disease: Antioxidant therapeutic targets. Current Drug TargetsInflammation \& Allergy, 1, 291-315. doi:10.2174/1568010023344607

[8] Fogh, K. and Kragballe, K. (2000) Eicosanoids in inflammatory skin diseases. Prostaglandins \& Other Lipid Mediators, 63, 43-54. doi:10.1016/S0090-6980(00)00096-4

[9] Case, J.P. (2001) Old and new drugs used in rheumatoid arthritis: A historical perspective. American Journal of Therapeutics, 8, 123-143. doi:10.1097/00045391-200103000-00007

[10] Loung, B.T., Chong, B.S. and Lowder, D.M. (2000) Treatment options for rheumatoid arthritis: Celecoxib, leflunomide, etanercept, and infliximab. The Annals of Pharmacotherapy, 34, 743-760. doi:10.1345/aph.19344

[11] Walsh, G.M. (2011) Novel cytokine-directed therapies for asthma. Discovery Medicine, 11, 283-291.

[12] Afeltra, A. (2001) Treatment of rheumatoid arthritis: New therapeutic approaches with biological agents. Endocrine, Metabolic \& Immune Disorders-Drug Targets, 1, 45-65. doi: $10.2174 / 1568008013341677$

[13] Ito, K. (2006) Update on glucocorticoid action and resistance. Journal of Allergy and Clinical Immunology, 117, 522-543. doi:10.1016/j.jaci.2006.01.032

[14] Strehl, C., Spies, C.M. and Buttgereit, F. (2011) Pharmacodynamics of glucocorticoids. Clinical and Experimental Rheumatology, 29, S13-S18.

[15] Schacke, H., Docke, W.D. and Asadullah, K. (2002) Mechanisms involved in the side effects of glucocorticoids. Pharmacology \& Therapeutics, 96, 23-43. doi:10.1016/S0163-7258(02)00297-8

[16] Ezeamuzie, C.I. and Edafiogho, I.O. (2012) Enhydrazone esters for treating asthma, allergy and inflammation. US Patent No. 8,324,422 B2.

[17] Edafiogho, I.O., Kombian, S.B., Ananthalakshmi, K.V., Salama, N.N., Eddington, N.D., Wilson, T.L., et al. (2007) Enaminones: Exploring additional therapeutic activities. Journal of Pharmaceutical Sciences, 96, 2509-2531. doi:10.1002/jps.20967

[18] Edafiogho, I.O., Phillips, O.A., Udo, E.E., Samuel, S. and Rethish, B. (2009) Synthesis, antibacterial and anticonvulsant evaluations of some cyclic enaminones. European Journal of Medicinal Chemistry, 44, 967-975. doi:10.1016/j.ejmech.2008.07.005

[19] El-Hashim, A., Yousefi, S., Edafiogho, I., Raghupathy, R., Yousif, M. and Simon, H.-U. (2010) Anti-inflammatory and immunosuppressive effects of the enaminone E121. European Journal of Pharmacology, 632, 73-78. doi:10.1016/j.ejphar.2009.12.004

[20] El-Hashim, A.Z., Edafiogho, I.O., Jaffal, S.M., Yousif, 
M.H., Ezeamuzie, C.I. and Kombian, S.B. (2011) Antitussive and bronchodilatory mechanisms of action for the enaminone E121. Life Sciences, 89, 378-387. doi:10.1016/j.lfs.2011.07.007

[21] Ezeamuzie, C.I. and Shihab, P.K. (2010) Interactions between theophylline and salbutamol on cytokine release in human monocytes. Journal of Pharmacology and Experimental Therapeutics, 334, 302-309. doi:10.1124/jpet.109.163238

[22] Cox, C.E. (2012) Persistent systemic inflammation in chronic critical illness. Respiratory Care, 57, 859-864. doi:10.4187/respcare.01719

[23] Franks, A.L. and Slansky, J.E. (2012) Multiple associations between a broad spectrum of autoimmune diseases, chronic inflammatory diseases and cancer. Anticancer Research, 32, 1119-1136.
[24] Gotzche, P. (2002) Non-steroidal anti-inflammatory drugs. Clinical Evidence, 8, 1203-1211.

[25] Rothstein, R. (1998) Safetyt profiles of leading non-steroidal anti-inflammatory drugs. American Journal of Medicine, 105, 39S-43S. doi:10.1016/S0002-9343(98)00280-0

[26] Katsanou, V., Dimitriou, M. and Kontoyiannis, D.L. (2006) Post-transcriptional regulators in inflammation: Exploring new avenues in biological therapeutics. Ernst Schering Foundation Symposium Proceedings, 4, 37-57.

[27] Stellato, C. (2004) Post-transcriptional and non-genomic effects of glucocorticoids. Proceedings of the American Thoracic Society, 1, 255-263. doi:10.1513/pats.200402-015MS 